\title{
USING WOOD AND BONE ASH TO REMOVE METAL IONS FROM SOLUTIONS
}

\author{
K. CHOJNACKA* \\ I. MICHALAK
}

Received: $14 / 08 / 08$

Accepted: $16 / 12 / 08$

\author{
Institute of Inorganic Technology and Mineral Fertilizers \\ Wrocław University of Technology \\ ul. Smoluchowskiego 25, 50-372 Wroclaw, Poland
}

*to whom all correspondence should be addressed: e-mail: katarzyna.chojnacka@pwr.wroc.pl

\begin{abstract}
In the present work, wood and bone ash were used to remove metal cations from solutions. Cation-removal capacity of the ashes was analyzed by potentiometric titration. It was found that the capacity of wood ash was two times higher $\left(37.3 \mathrm{meq} \mathrm{g}^{-1}\right)$ than bone ash $\left(15.2 \mathrm{meq} \mathrm{g}^{-1}\right)$. Kinetics of metal ions removal by both ashes was described with pseudo-second order equation and Langmuir model was employed to describe equilibrium of the process. Wood ash had better removal properties than bone ash - at the same experimental conditions biosorption capacity at equilibrium for wood ash was 2 times higher $\left(244 \mathrm{mg} \mathrm{g}^{-1}\right)$ than for bone ash $\left(123 \mathrm{mg} \mathrm{g}^{-1}\right)$.

Promising results were also obtained for wood ash, which was capable of removing $67.9 \%$ of $\mathrm{Zn}(\mathrm{II})$ ions, $70.4 \%$ of $\mathrm{Cd}(\mathrm{II})$ ions, $92.8 \%$ of $\mathrm{Cu}(\mathrm{II})$ ions and $99.1 \%$ of $\mathrm{Cr}(\mathrm{III})$ ions from model solution of wastewater from metallurgical industry and $84.5 \%$ of $\mathrm{Cr}(\mathrm{III})$ ions from the postbiosorption solution from the production process of biological feed additives. The utilization of ashes of biological origin was found to be a promising alternative to conventional processes of wastewater treatment.
\end{abstract}

KEYWORDS: wood and bone ash, kinetics, equilibrium, $\mathrm{Cr}(\mathrm{III}), \mathrm{Cd}(\mathrm{II}), \mathrm{Zn}(\mathrm{II}), \mathrm{Cu}(\mathrm{II}), \mathrm{Ni}(\mathrm{II})$ ions, removal of toxic metal ions, wastewater.

\section{INTRODUCTION}

In the recent years, there is an increasing interest in the application of materials of biological origin in heavy metal ions removal from aqueous solutions. In the future, such materials might gain a special attention, since the cost of these materials is much lower than the cost of commercial adsorbents, such as activated carbon or ion-exchange resins (Al-Asheh et al., 2002).

Many agricultural by-products, activated sludge, specially propagated the biomass of algae, fungi, yeast, bacteria, algae from the environment that are available at little or no cost have been reported to be capable of removing substantial amounts of toxic metals from aqueous solutions (Veglio' and Beolchini, 1997; Volesky, 1990). Removal of metal ions involves relatively rapid metal-sequestering mechanisms related to the cell surface. In most cases, the metal bound on the biosorbent can be eluted, biomass can be regenerated and reused in multiple cycles.

Apart form mentioned natural biosorbents, in the literature, a special attention was also paid to the application of fly ash, which is generated during burning of coal, as a useful adsorbent (Alinnor, 2007; Cho et al., 2005; Erol et al., 2005). Fly ash is a strongly alkaline material and its surface is negatively charged at high $\mathrm{pH}$. Hence, it can be expected that metal ions can be removed from aqueous solutions by precipitation, electrostatic adsorption (Cho et al., 2005) and ion exchange (Erol et al., 2005).

In the present paper, wood and bone ashes are proposed as materials for removal of mainly $\mathrm{Cr}(\mathrm{III}), \mathrm{Cd}(\mathrm{II}), \mathrm{Zn}(\mathrm{II}), \mathrm{Cu}(\mathrm{II})$ and $\mathrm{Ni}(\mathrm{II})$ ions from aqueous solutions. For the removal of toxic elements, biosorption process was applied. It is a surface phenomenon and relies on the binding of metal ions to the functional groups present on the sorbent. 
The combustion of wood and agricultural residues generates large amounts of ashes (Reijnders, 2007). The majority of these wastes is disposed to landfills. However, increasing costs and the difficulties in acquiring new landfill sites encourage to look for alternative methods of disposal (Demeyer et al., 2001). Wood ash, which is formed in the combustion process of wood as renewable fuel and the combustion of slaughter residues (Chojnacka, 2005), can be applied to soils. This enables to recycle nutrients $\mathrm{Ca}, \mathrm{K}, \mathrm{Mg}, \mathrm{P}$ and to deacidify a soil (Górecka et al., 2006, Demeyer et al., 2001). Ribbing (2007) suggested that non-coal ashes could be also applied as a material in the construction of roads and surfaces in landfills, as ballast or filler in concrete. In the literature, an increasing attention is paid to the application of natural ashes as adsorbents. Das et al. (2007) used plant ash to remove iron from groundwater. The mechanism proposed was precipitation of ferric ions by increasing $\mathrm{pH}$, achieved by dissolution of potassium hydroxide and oxide. Also, palm ash was proposed as biosorbent of Direct blue 71 dye $\left(\mathrm{C}_{40} \mathrm{H}_{28} \mathrm{~N}_{7} \mathrm{NaO}_{13} \mathrm{~S}_{4}\right)$. Very high adsorption capacity obtained in the experiment, suggested that palm ash could be employed as a low-cost alternative to commercial activated carbon (Ahmad et al., 2007).

Recently, the utilization of animal bones is of particular concern. Due to the recent problem with bovine spongiform encephalopathy (BSE) crisis in the European beef industry, the use of animal derived products to feed cattle is now restricted. Feeding with meat and bone meal (MBM) to cattle, sheep or goats has been banned within the European Union since July 1994. Also, import and export of MBM to/from/within the European Union has been banned since December 2000. As a consequence, it is necessary to elaborate new methods of utilization of animal by-products. One option of such disposal is the incineration of material such as meat and bone meal residues. Dedicated incineration plants for MBM, as currently used in e.g., Belgium and England, only appear reasonable when sufficient quantities of MBM can be guaranteed in the long term (Conesa et al., 2005). The second disposal option is pyrolysis. Animal wastes could be converted by pyrolysis into fuels, but it is also suggested, that the solid residue could be used for enrichment of agricultural soil with nutrients and minerals (Chaala and Roy, 2003). This is aimed to assure epidemiological safety. The problem of utilization of ash from thermal processing of slaughter wastes arose. There has not been found large-scale method of bone ash utilization so far. In the literature it can be found, that the main attention of researchers was paid to the application of animal bones in removal process of heavy metals from aqueous solutions (Chojnacka, 2005; Banat et al., 2000; AlAsheh et al., 1999; Al-Asheh et al., 2002). Nevertheless, Deydier et al. (2003) used meat and bone meal combustion residue as a low-cost material to remove lead ions from effluents. This residue was considered as an apatite-rich material and was used as a low-cost substitute of hydroxyapatite in removal of lead ions from wastewater. The mechanism of metal ions removal was found to be as in pure apatite: surface complexation and calcium hydroxyapatite dissolution, followed by precipitation of less soluble lead hydroxyapatite (Deydier et al., 2003). In the present work, the sorption properties of two materials of biological origin - wood and bone ash were investigated. The experiments were divided into three groups: the first concerned the general characteristics of biosorption properties of the examined biosorbents, the second aimed to establish the effect of process parameters, such as initial concentration of metal ions $\left(C_{0}\right)$, ash concentration $\left(C_{S}\right)$, temperature, initial $\mathrm{pH}$ on process kinetics and the effect of ash concentration, initial $\mathrm{pH}$, and temperature on process equilibrium. These preliminary experiments were conducted on $\mathrm{Cr}(\mathrm{III})$ ions. In the last experiment, the applicability of wood and bone ash to remove toxic metals ( $\mathrm{Cr}(\mathrm{III}), \mathrm{Cd}(\mathrm{II}), \mathrm{Zn}(\mathrm{II}), \mathrm{Cu}(\mathrm{II}), \mathrm{Ni}(\mathrm{II}))$ from two model solutions was determined (the first came from metallurgical industry and the second from the production process of biological feed additives based on microalgal biomass).

\section{MATERIALS AND METHODS}

\subsection{Ash preparation}

Wood ash was obtained by the combustion of oak wood in a residential fireplace. The characteristic of the combustion process was as follows: power $-15 \mathrm{~kW}$, combustion rate 0.06 $-0.07 \mathrm{~m}^{3}$ of wood per day. The collected ash was mixed and grinded. Bone ash was obtained from chickens' bones, which were previously cooked, cleaned from the residual meat and 
finally grinded. Then, the bones were combusted in the temperature $600{ }^{\circ} \mathrm{C}$ for 4 hours in the laboratory oven (Carbolite CWF 1200).

\subsection{Potentiometric titration of the ashes}

Potentiometric titration of the ashes was performed in order to determine the acidic dissociation constants and the total concentrations of the functional groups present in ash that are responsible for cations binding. The deionized water (blank sample) and $0.2 \mathrm{~g}$ of bone ash (for wood ash $0.02 \mathrm{~g}$ of material was used) suspended in deionized water $(200 \mathrm{ml}$ ) were titrated with $\mathrm{HCl}$ and $\mathrm{NaOH}$ in the range of $\mathrm{pH} 2.5-11.5$. For the titration, the solutions of 0.1 $\mathrm{mol} \mathrm{I}^{-1} \mathrm{HCl}$ and $\mathrm{NaOH}$ were used. The procedure was described previously (Chojnacka et al., 2005).

\subsection{Batch biosorption experiments in single-metal system}

The experiments were performed in $250 \mathrm{ml}$ Erlenmeyer flasks containing $200 \mathrm{ml}$ of $\mathrm{Cr}$ (III) solution (for kinetic experiments) and $20 \mathrm{ml}$ (for equilibrium experiments) in thermostated water bath shaker at $150 \mathrm{rpm}$. The solutions of $\mathrm{Cr}(\mathrm{III})$ ions were prepared in deionized water (by dissolving appropriate amounts of $\mathrm{Cr}\left(\mathrm{NO}_{3}\right)_{3} \cdot 9 \mathrm{H}_{2} \mathrm{O}$ (from POCh S.A. Gliwice, Poland)). pH of the solutions was adjusted with $0.1 \mathrm{~mol} \mathrm{I}^{-1}$ solution $\mathrm{NaOH} / \mathrm{HCl}$ (from POCh S.A. Gliwice). $\mathrm{pH}$ was measured with $\mathrm{pH}$ - meter Mettler-Toledo (Seven Multi) equipped with an electrode InLab413 with compensation of temperature. Experimental conditions for kinetics and equilibrium of biosorption of $\mathrm{Cr}(\mathrm{III})$ ions is presented in Table 1.

Table 1. Experimental conditions for kinetics and equilibrium of biosorption of $\mathrm{Cr}(\mathrm{III})$ ions

\begin{tabular}{|c|c|c|c|c|c|c|c|c|}
\hline \multirow{2}{*}{$\begin{array}{l}\text { Para- } \\
\text { meter }\end{array}$} & \multicolumn{4}{|c|}{ Kinetic experiments } & \multicolumn{4}{|c|}{ Equilibrium experiments } \\
\hline & & Wood ash & & Bone ash & & Wood ash & & Bone ash \\
\hline \multirow[t]{4}{*}{$\mathrm{pH}$} & \multicolumn{2}{|c|}{$3 ; 4 ; 5$} & \multicolumn{2}{|c|}{$3 ; 4 ; 5$} & \multicolumn{2}{|c|}{$3 ; 4 ; 5$} & \multicolumn{2}{|c|}{$3 ; 4 ; 5$} \\
\hline & $C_{\mathrm{S}}$ & $1.0 \mathrm{~g} \mathrm{I}^{-1}$ & $C_{\mathrm{S}}$ & $0.1 \mathrm{~g} \mathrm{I}^{-1}$ & $C_{S}$ & $0.2 \mathrm{~g} \mathrm{I}^{-1}$ & $C_{S}$ & $0.5 \mathrm{~g} \mathrm{I}^{-1}$ \\
\hline & $\mathrm{T}$ & $20^{\circ} \mathrm{C}$ & $\mathrm{T}$ & $20^{\circ} \mathrm{C}$ & $\mathrm{T}$ & $20^{\circ} \mathrm{C}$ & $\mathrm{T}$ & $20^{\circ} \mathrm{C}$ \\
\hline & $C_{0}$ & $200 \mathrm{mg} \mathrm{l}^{-1}$ & $C_{0}$ & $100 \mathrm{mg} \mathrm{I}^{-1}$ & $C_{0}$ & $50-300 \mathrm{mg} \mathrm{I}^{-1}$ & $C_{0}$ & $25-300 \mathrm{mg} \mathrm{l}^{-1}$ \\
\hline \multirow[t]{4}{*}{$\mathrm{T}\left({ }^{\circ} \mathrm{C}\right)$} & \multicolumn{2}{|c|}{$20 ; 30 ; 40 ; 60$} & \multicolumn{2}{|c|}{$20 ; 30 ; 50$} & \multicolumn{2}{|c|}{$20 ; 40 ; 60$} & \multicolumn{2}{|c|}{$20 ; 40 ; 60$} \\
\hline & $C_{S}$ & $1.0 \mathrm{~g} \mathrm{l}^{-1}$ & $C_{S}$ & $0.75 \mathrm{~g} \mathrm{I}^{-1}$ & $C_{s}$ & $0.2 \mathrm{~g} \mathrm{I}^{-1}$ & $C_{s}$ & $0.5 \mathrm{~g} \mathrm{I}^{-1}$ \\
\hline & $\mathrm{pH}$ & 4 & $\mathrm{pH}$ & 5 & $\mathrm{pH}$ & 5 & $\mathrm{pH}$ & 5 \\
\hline & $C_{0}$ & $200 \mathrm{mg} \mathrm{I}^{-1}$ & $C_{0}$ & $100 \mathrm{mg} \mathrm{I}^{-1}$ & $C_{0}$ & $50-300 \mathrm{mg} \mathrm{I}^{-1}$ & $C_{0}$ & $25-300 \mathrm{mg} \mathrm{l}^{-1}$ \\
\hline \multirow[t]{4}{*}{$C_{\mathrm{s}}\left(\mathrm{g} \mathrm{I}^{-1}\right)$} & \multicolumn{2}{|c|}{$\begin{array}{l}0.05 ; 0.1 ; 0.2 ; 0.5 ; \\
1.0\end{array}$} & \multicolumn{2}{|c|}{$\begin{array}{l}0.1 ; 0.2 ; 0.5 ; 0.75 ; \\
1.0\end{array}$} & \multicolumn{2}{|c|}{$0.1 ; 0.2 ; 0.5$} & \multicolumn{2}{|c|}{$\begin{array}{l}0.1 ; 0.2 ; 0.5 ; 0.75 ; \\
1.0 ; 2.0\end{array}$} \\
\hline & $\mathrm{pH}$ & 4 & $\mathrm{pH}$ & 5 & $\mathrm{pH}$ & 5 & $\mathrm{pH}$ & 5 \\
\hline & $\mathrm{T}$ & $20^{\circ} \mathrm{C}$ & $\mathrm{T}$ & $20^{\circ} \mathrm{C}$ & $\mathrm{T}$ & $20^{\circ} \mathrm{C}$ & $\mathrm{T}$ & $20^{\circ} \mathrm{C}$ \\
\hline & $C_{0}$ & $100 \mathrm{mg} \mathrm{l}^{-1}$ & $C_{0}$ & $100 \mathrm{mg} \mathrm{l}^{-1}$ & $C_{0}$ & $50-300 \mathrm{mg} \mathrm{l}^{-1}$ & $C_{0}$ & $25-300 \mathrm{mg} \mathrm{l}^{-1}$ \\
\hline \multirow[t]{4}{*}{$C_{0}\left(\mathrm{mg} \mathrm{l}^{-1}\right)$} & \multicolumn{2}{|c|}{$100 ; 200 ; 300$} & \multicolumn{2}{|c|}{$100 ; 200 ; 300$} & & & & \\
\hline & $C_{\mathrm{s}}$ & $1.0 \mathrm{~g} \mathrm{I}^{-1}$ & $C_{S}$ & $0.75 \mathrm{~g} \mathrm{I}^{-1}$ & & & & \\
\hline & $\mathrm{pH}$ & 4 & $\mathrm{pH}$ & 5 & & & & \\
\hline & $\mathrm{T}$ & $20^{\circ} \mathrm{C}$ & $\mathrm{T}$ & $20^{\circ} \mathrm{C}$ & & & & \\
\hline
\end{tabular}

The contact time for all equilibrium experiments was 90 minutes for wood ash and 120 minutes for bone ash (determined from the kinetic experiments). Equilibrium experiments of biosorption of $\mathrm{Cd}(\mathrm{II})$ and $\mathrm{Zn}(\mathrm{II})$ ions were performed at the parameters, which were selected as the best in the case of biosorption of $\operatorname{Cr}(\mathrm{III})$ ions $\left(1.0 \mathrm{~g} \mathrm{I}^{-1}\right.$, T $\left.20^{\circ} \mathrm{C}, \mathrm{pH} 5, \mathrm{C}_{0} 25-300 \mathrm{mg} \mathrm{l}^{-1}\right)$. The solutions of metal ions were prepared in deionized water by dissolving appropriate amounts of $\mathrm{Cd}\left(\mathrm{NO}_{3}\right)_{2} \cdot 4 \mathrm{H}_{2} \mathrm{O}$ and $\mathrm{ZnSO}_{4}$ (from POCh S.A. Gliwice). 


\subsection{Batch biosorption experiments in multi-metal system}

For the biosorption experiments in multi-metal system two solutions were chosen: from the metallurgical industry (Łebkowska and Karwowska, 2003) and from the production process of mineral feed additives based on microalgal biomass (Chojnacka, 2007). The composition of the solutions was assumed to be as follows - the first one: range of the concentration of metal ions: 5 - $100 \mathrm{mg} \mathrm{l}^{-1}$ of $\mathrm{Zn}(\mathrm{II}), 5-50 \mathrm{Ni}(\mathrm{II})$ and $\mathrm{Cu}(\mathrm{II})$ ions, $1.5-30 \mathrm{mg} \mathrm{I}^{-1}$ of $\mathrm{Cd}(\mathrm{II})$ ions and 15 $100 \mathrm{mg} \mathrm{I}^{-1}$ of $\mathrm{Cr}$ (III) ions and the second: $190 \mathrm{mg} \mathrm{l}^{-1}$ of $\mathrm{Cr}(\mathrm{III})$ ions. For their preparation, the following salts were used: $\mathrm{ZnSO}_{4}, \mathrm{NiSO}_{4} \cdot 7 \mathrm{H}_{2} \mathrm{O}, \mathrm{CuSO}_{4} \cdot 5 \mathrm{H}_{2} \mathrm{O}, \mathrm{Cd}\left(\mathrm{NO}_{3}\right)_{2} \cdot 4 \mathrm{H}_{2} \mathrm{O}$ and $\mathrm{Cr}\left(\mathrm{NO}_{3}\right)_{3} \cdot 9 \mathrm{H}_{2} \mathrm{O}$. The experiments were performed at room temperature and $\mathrm{pH} 5$. The concentration of wood ash was $0.2 \mathrm{~g} \mathrm{l}^{-1}$ and of bone ash $1.0 \mathrm{~g} \mathrm{l}^{-1}$ in both model solutions.

\subsection{Analytical methods}

\subsubsection{Analysis of $\mathrm{Cr}(\mathrm{III})$ ions concentration}

Samples of ash suspension were taken to determine residual concentration of $\operatorname{Cr}($ III) ions in the solution. Before the analysis, samples were filtered through medium paper filter. The concentration of metal ions in the solution was determined directly spectrophotometrically by complexation with EDTA by Varian Cary 50 Conc. Instrument (Yongnian et al., 2002). The concentrations used in the preparation of the calibration curve were determined by Inductively Coupled Plasma-Optical Emission Spectrometer (Varian VISTA-MPX ICP-OES) in the Chemical Laboratory of Multielemental Analysis at Wrocław University of Technology accredited by ILAC-MRA and PCA. For the preparation of standard solutions $\left(1.0,10,100 \mathrm{mg} \mathrm{l}^{-1}\right)$ the multielemental standard (100 $\mathrm{mg} \mathrm{I}^{-1}$ Astasol囚, Czech Republic) was used (Chojnacka, 2006). The presented data are the arithmetic average from three measurements.

\subsubsection{Multielemental analysis of the wastewater and ash composition}

Approximately $0.5 \mathrm{~g}$ of the natural ashes was digested with $5 \mathrm{ml}$ of concentrated nitric acid (Supra pure grade from Merck) in a microwave oven (type Milestone MLS-1200 MEGA). The solution after mineralization was diluted to $50 \mathrm{ml}$. The concentrations of metal ions in the samples of digested ashes, as well as in model solution from metallurgical industry and in the wastewaters from biosorption process before and after treatment with wood and bone ash were determined by ICP-OES method.

\section{RESULTS and DISCUSSION}

\subsection{Characterization of wood and bone ash}

Table 2 shows the mineral composition of the ashes samples used in this study. The main constituents of wood and bone ash are alkali and alkaline earth metals $(\mathrm{Ca}, \mathrm{K}, \mathrm{Mg}, \mathrm{Na})$, microelements (Mn, Fe) and Al. Wood ash contained $17.4 \%$ of $\mathrm{Ca}(\mathrm{II}), 4.27 \%$ of $\mathrm{K}(\mathrm{I}), 1.15 \%$ of $\mathrm{Mg}(\mathrm{II}), 0.673 \%$ of $\mathrm{Na}(\mathrm{I})$, whereas bone ash: $22.5 \%$ of $\mathrm{Ca}(\mathrm{II}), 1.34 \%$ of $\mathrm{K}(\mathrm{I}), 0.597 \%$ of $\mathrm{Mg}(\mathrm{II})$ and $0.886 \%$ of $\mathrm{Na}(\mathrm{I})$. From these results it can be expected, that theoretically bone ash will be a better material for the removal of heavy metal ions from wastewaters, due to higher concentration of light metals. The content of toxic metals in bone ash is smaller than in wood ash. It is important to check, whether wood and bone ash does not cause secondary pollution of treated wastewater.

\subsection{Mechanism of the metal ions removal by ashes}

The identification of functional groups on the ashes surface is one of the key issues in understanding the mechanism of metal binding. The acid site densities and acidity constants were determined by potentiometric titration. The experimental data were fitted to the models elaborated previously (Chojnacka et al., 2005a), which considered the presence of one, two or three types of functional groups. The highest regression coefficients were obtained for the assumption of the existence of three types of functional groups $\left(R^{2} 0.999\right.$ for wood ash and $R^{2}$ 0.989 for bone ash). For the titration of the $0.02 \mathrm{~g}$ suspension of wood ash, 1.77 meq of titrant was used, and for titration of deionized water - 1.01 meq of titrant. In the case of bone ash, for the titration of the $0.2 \mathrm{~g}$ suspension of ash, 4.26 meq of titrant was used and for water 1.22. From the difference between these two values, the total cation removal capacity was determined, which for wood ash was $38.0 \mathrm{meq} \mathrm{g}^{-1}$ and for bone ash as $15.2 \mathrm{meq} \mathrm{g}^{-1}$ (meq milliequivalent is the molar unit, which considers the valency of an ion). It was found that 
cation-removal capacity of wood ash was two times higher than bone ash. The examined ashes possessed three functional groups with distinguishable $\mathrm{p} K_{\mathrm{a}}$ on the surface: the first one is probably carbonate, the second phosphate and the third group hydroxyl. The acidity constants and acid site densities are shown in Table 3. Wood ash possessed similar values of acidity constants to coal fly ash reported in the literature, which for these three acid sites were 2.7, 7.8 and 11.0, respectively (Wang et al., 2004).

Table 2. Mineral composition of wood and bone ash

\begin{tabular}{|c|c|c|c|}
\hline \multirow{2}{*}{\multicolumn{2}{|c|}{ Element }} & \multicolumn{2}{|c|}{ Concentration ( $\mathrm{mg} \mathrm{kg}^{-1}$ of dry mass) } \\
\hline & & Wood ash & Bone ash \\
\hline \multirow{8}{*}{ 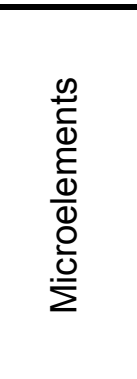 } & $\mathrm{Mn}$ & 5544 & 4.29 \\
\hline & $\mathrm{Zn}$ & 518 & 215 \\
\hline & $\mathrm{Cu}$ & 134 & 2.87 \\
\hline & Co & 6.76 & 1.09 \\
\hline & $\mathrm{Fe}$ & 1705 & 298 \\
\hline & Mo & 1.64 & 1.22 \\
\hline & $\mathrm{Cr}$ & 11.5 & 6.48 \\
\hline & $\mathrm{B}$ & 302 & 4.16 \\
\hline \multirow{5}{*}{ 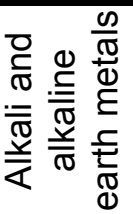 } & $\mathrm{K}$ & 42655 & 13372 \\
\hline & $\mathrm{Ca}$ & 173879 & 225372 \\
\hline & $\mathrm{Mg}$ & 11523 & 5968 \\
\hline & $\mathrm{Na}$ & 6732 & 8861 \\
\hline & $\mathrm{Ba}$ & 892 & 36.7 \\
\hline \multirow{3}{*}{ 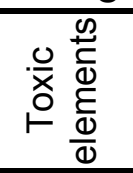 } & $\mathrm{Cd}$ & 2.89 & 0.232 \\
\hline & $\mathrm{Ni}$ & 27.1 & 3.73 \\
\hline & $\mathrm{Pb}$ & 29.4 & 1.92 \\
\hline \multirow{4}{*}{ 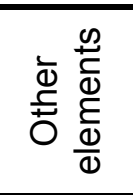 } & $\mathrm{Ti}$ & 22.6 & 1.52 \\
\hline & $\mathrm{Al}$ & 7251 & 14.8 \\
\hline & $\mathrm{Ag}$ & 2.33 & 0.305 \\
\hline & V & 125 & 56.8 \\
\hline
\end{tabular}

Table 3. Functional groups on the surface of bio-ashes

\begin{tabular}{ccccc}
\hline \multirow{2}{*}{$\begin{array}{c}\text { Functional } \\
\text { group }\end{array}$} & \multicolumn{2}{c}{ Acidity constant $\mathrm{p} K_{\mathrm{a}}$} & \multicolumn{2}{c}{ Acid site density $\left(\mathrm{meq} \mathrm{g}^{-1}\right)$} \\
\cline { 2 - 5 } & Wood ash & Bone ash & Wood ash & Bone ash \\
\hline 1 & 2.39 & 3.54 & 11.8 & 2.02 \\
2 & 8.00 & 6.33 & 7.50 & 1.57 \\
3 & 11.1 & 11.0 & 21.8 & 4.71 \\
\hline
\end{tabular}

Multielemental analysis of digested ashes showed that bone ash contained more light metal ions than wood ash. Their concentration presented in Table 2 included the total concentration - inside and outside the sorbent. Biosorption is a surface phenomenon and in this process participate only light metal ions, which are present on the surface of the ash. Therefore on the basis of the total composition of light metal ions in ash it was supposed that bone ash would be better biosorbent than wood ash. However, potentiometric titration of the ash showed that the density of acidic sites on the surface of wood ash was higher than on the surface of bone ash. These functional groups play a key role in the biosorption process of cations through ionexchange mechanism. Therefore, we concluded that wood ash possessed better biosorption properties than bone ash.

The expected mechanism of metal ions removal from aqueous solutions by wood ash can involve: precipitation, electrostatic adsorption (Cho et al., 2005) and ion exchange (Erol et al., 2005). As pH increased from 3 to 5 , it can be expected that the number of positively charged sites decreases and the number of negatively charged sites increases on the surface of wood and bone ash. A negatively charged surface sites of the ashes favour the adsorption of cationic metal ions due to electrostatic attraction. Since the experiments were performed in 
$\mathrm{pH}$ range $3-5$, it is necessary to consider the chemical speciation of $\mathrm{Cr}(\mathrm{III})$ ions under these conditions. In this range, $\mathrm{Cr}(\mathrm{III})$ ions occur as $\mathrm{CrOH}^{2+}$, as a result of hydrolysis, according to the generalized expression: $\mathrm{M}^{3+}($ aq. $)+n \mathrm{H}_{2} \mathrm{O}=\mathrm{M}(\mathrm{OH})^{3-n}+n \mathrm{H}^{+}\left(\right.$where $\left.\mathrm{M}^{3+}=\mathrm{Cr}^{3+}\right)$. At $\mathrm{pH}$ higher than $5, \mathrm{Cr}(\mathrm{III})$ ions begin to precipitate as $\mathrm{Cr}(\mathrm{OH})_{3}$ (Yun et al., 2001), and can be adsorbed on the surface of examined ashes.

At higher $\mathrm{pH}$, ashes could act as a precipitant agent similarly to lime, which is used in chemical precipitation of heavy metals from inorganic effluent. In the case of removal of $\mathrm{Zn}(\mathrm{II})$, $\mathrm{Cd}(\mathrm{II}), \mathrm{Mn}(\mathrm{II}), \mathrm{Mg}(\mathrm{II})$ from the waste water with the use of lime, hydroxides are precipitated at elevated $\mathrm{pH}$, but values of $\mathrm{pH} 9.5$ or greater are necessary for the effective removal (Charerntanyarak, 1999). Similarly to lime or calcium hydroxide, which are the most commonly employed precipitant agents, ash could be also applied in wastewater treatment to precipitate heavy metal ions, because of the alkalization properties. The most important characteristic of fly ash is the $\mathrm{Ca}$ (II) content, that provides alkalinity. In the case of wood ash, examined in this study, $\mathrm{Ca}$ (II) constituted $17.4 \%$ of all light metals determined by ICP-OES method, which occurred in the raw wood ash, and for bone ash $22.5 \%$. This means, that in higher $\mathrm{pH}$, precipitation could constitute a dominant mechanism of toxic metal ions removal. Since $\mathrm{Ca}(\mathrm{II})$ in the ash is in the form of $\mathrm{CaO}$, it can be assumed, that the following reactions occur: $\mathrm{Me}_{\text {alk. } \mathrm{a}} \mathrm{O}+\mathrm{H}_{2} \mathrm{O}+\mathrm{Me}_{\text {tox. }}{ }^{\mathrm{b}+}=\mathrm{Me}_{\text {tox }}(\mathrm{OH})_{\mathbf{b}} \downarrow+\mathrm{Me}_{\text {alk. }}{ }^{\mathrm{a}}$, where: $\mathrm{a}-$ charge $^{+1}$ or $^{+2} ; \mathrm{Me}_{\text {alk }}-$ alkali (e.g. $\mathrm{K}(\mathrm{I}), \mathrm{Na}(\mathrm{I})$ ) and alkaline earth metals (e.g. $\mathrm{Mg}(\mathrm{II}), \mathrm{Ca}(\mathrm{II}), \mathrm{Ba}(\mathrm{II})$ ); $\mathrm{Me}_{\text {tox }}$ toxic elements (e.g. $\mathrm{Cd}(\mathrm{II}), \mathrm{Pb}(\mathrm{II}), \mathrm{Zn}(\mathrm{II}), \mathrm{Cu}(\mathrm{II}), \mathrm{Ni}(\mathrm{II})$ ). For example: $\mathrm{CaO}+\mathrm{H}_{2} \mathrm{O}+\mathrm{Cu}^{2+}=$ $\mathrm{Cu}(\mathrm{OH})_{2} \downarrow+\mathrm{Ca}^{2+}$.

\subsection{Batch biosorption experiments of $\mathrm{Cr}(\mathrm{III})$ ions in single-metal system}

\subsubsection{Kinetics of biosorption of $\mathrm{Cr}$ (III) ions}

Kinetics of biosorption of $\mathrm{Cr}(\mathrm{III})$ ions by bio-ashes was described by pseudo-second order model (1):

$\frac{\mathrm{dq}}{\mathrm{dt}}=\mathrm{k}_{2, \mathrm{ad}} \cdot\left(\mathrm{q}_{\mathrm{eq}}-\mathrm{q}\right)^{2}$

where $q_{\mathrm{eq}}$ and $q$ are the amounts of adsorbed metal ions on the adsorbent at equilibrium and at time $t$, respectively $\left(\mathrm{mg} \mathrm{g}^{-1}\right)$ and $k_{2}$,ad is the rate constant of second-order adsorption $(\mathrm{g}$ $\left.\mathrm{mg} \cdot \mathrm{min}^{-1}\right)$. In the literature it is reported that pseudo-second order model was used to describe sorption of Direct blue 71 dye by palm ash (Ahmad et al., 2007). The kinetic experiments of the removal process of $\mathrm{Cr}(\mathrm{III})$ ions were conducted to determine the contact time required to reach the sorption equilibrium and to assess the impact of process parameters $(\mathrm{pH}$, temperature, $C_{\mathrm{s}}, C_{0}$ ) on $q_{\mathrm{eq}}$ and on $k_{2 \text {,ad. }}$. The contact time needed to reach equilibrium was evaluated as 90 minutes for wood ash and 120 minutes for bone ash (as an example the effect of $\mathrm{pH}$ on the kinetics of the biosorption of $\mathrm{Cr}(\mathrm{III})$ ions by wood (a) and bone ash (b) is presented in Figure 1).

The effect of process parameters on $q_{\mathrm{eq}}$ and on $k_{2 \text {,ad }}$ is presented in Table 4.

Comparing the parameters of pseudo-second order model for wood and bone ash at different $\mathrm{pH}$, temperature, $C_{S}$ and $C_{0}$, it can be seen, that wood ash showed better metal ions removal properties than bone ash. It was observed, that the higher $\mathrm{pH}$ and $C_{0}$ and the lower $C_{\mathrm{S}}$, the higher value of $q_{\mathrm{eq}}$. The $\mathrm{pH}$ of the solution plays a very important role in the uptake of metal ions, since it determines the surface charge of the adsorbent (Alinnor, 2007). The highest sorption capacity for wood and bone ash was obtained at $\mathrm{pH} 5$ and the smallest at $\mathrm{pH} 3$. For both ashes $q_{\mathrm{eq}}$ in $\mathrm{pH} 5$ was almost 2 times higher than in $\mathrm{pH} 3$. The next parameter temperature did not influence significantly the removal process of metal ions. For wood and bone ash, the values of $q_{\mathrm{eq}}$ and $k_{2, \text { ad }}$ were comparable in all examined temperatures. Considering the influence of $C_{S}$ on $q_{\text {eq }}$, it can be seen, than wood ash had much better removal properties than bone ash. For example: $q_{\mathrm{eq}}$ for wood ash $\left(C_{\mathrm{S}} 1.0 \mathrm{~g} \mathrm{I}^{-1}, C_{0} 100 \mathrm{mg} \mathrm{l}^{-1}\right.$, $\mathrm{pH}$ 4) was $103 \mathrm{mg} \mathrm{g}^{-1}$ and for bone ash only $36.0 \mathrm{mg} \mathrm{g}^{-1}$, although the $\mathrm{pH}$ was even higher for the second ash $\left(C_{\mathrm{s}} 1.0 \mathrm{~g} \mathrm{I}^{-1}, C_{0} 100 \mathrm{mg} \mathrm{l}^{-1}, \mathrm{pH} 5\right)$, which should influence the $q_{\mathrm{eq}}$ value positively. The same trend was observed also for $C_{S} 0.1,0.2$ and $0.5 \mathrm{~g} \mathrm{l}^{-1}$. For both bio-ashes, the lower concentration of material in the solution, the higher the value of $q_{\text {eq. }}$. It is beneficial to conduct removal process of metal ions at higher biomass concentrations, because with increase of $C_{\mathrm{S}}$, the amount of ions bound from the solution also increased - for example for the concentration of wood ash $0.05 \mathrm{~g} \mathrm{I}^{-1}\left(q_{\mathrm{eq}} 270 \mathrm{mg} \mathrm{g}^{-1}\right)-13.5 \mathrm{mg}$ of $\mathrm{Cr}(\mathrm{III})$ ions were bound 
by the material from $1 \mathrm{~L}$ of the solution, for $C_{\mathrm{S}} 1.0 \mathrm{~g} \mathrm{l}^{-1}\left(q_{\mathrm{eq}} 103 \mathrm{mg} \mathrm{g}^{-1}\right.$ )- $103 \mathrm{mg} \mathrm{l}^{-1}$ (almost 8 times more). This conclusion is very important in design of wastewater treatment plant. As it was shown previously, the higher value of $\mathrm{pH}$ and the lower of $C_{\mathrm{S}}$, the higher value of $q_{\mathrm{eq}}$.are. Although biosorption of $\mathrm{Cr}(\mathrm{III})$ ions by wood ash was performed in different biosorption conditions $\left(C_{\mathrm{S}} 0.75 \mathrm{~g} \mathrm{I}^{-1}, 20^{\circ} \mathrm{C}, \mathrm{pH} 5\right)$ than by wood ash $\left(C_{\mathrm{S}} 1.0 \mathrm{~g} \mathrm{I}^{-1}, 20^{\circ} \mathrm{C}, \mathrm{pH} 4\right)$ for $C_{0}$ range $100-300 \mathrm{mg} \mathrm{I}^{-1}$, the value of $q_{\mathrm{eq}}$ were averagely $2.52 \pm 0.27$ higher for wood than for bone ash.

(a)

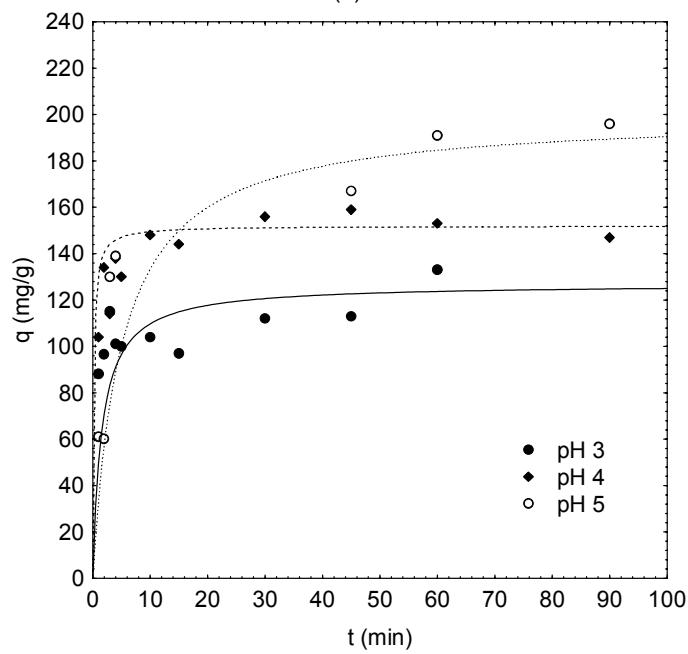

(b)

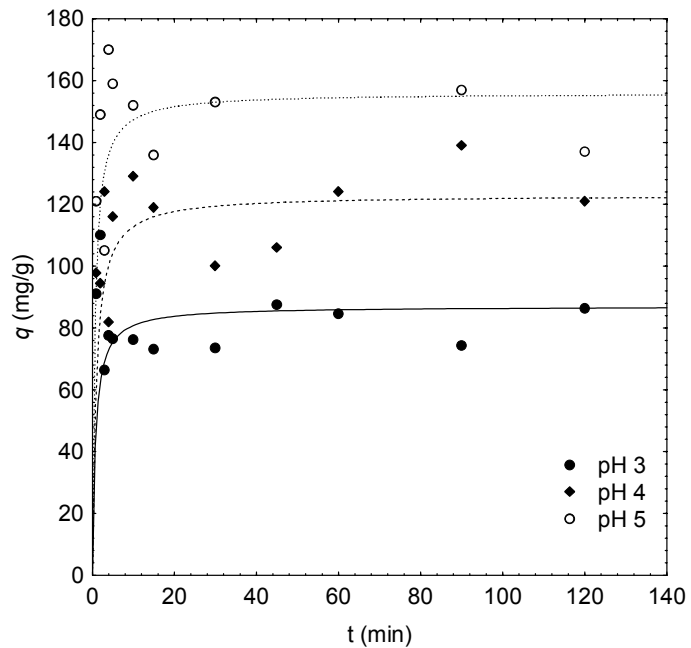

Figure 1. The effect of $\mathrm{pH}$ on the kinetics of the biosorption of $\mathrm{Cr}(\mathrm{III})$ ions by (a) wood $\left(20^{\circ} \mathrm{C}\right.$, $\left.C_{0} 200 \mathrm{mg} \mathrm{l}^{-1}, C_{S} 1.0 \mathrm{~g} \mathrm{l}^{-1}\right)$ and (b) bone ash $\left(20^{\circ} \mathrm{C}, C_{0} 100 \mathrm{mg} \mathrm{l}^{-1}, C_{S} 0.1 \mathrm{~g} \mathrm{l}^{-1}\right)$

Table 4. The comparison of parameters of pseudo-second order model for wood and bone ash at different $\mathrm{pH}$, temperatures, $\mathrm{C}_{\mathrm{S}}$ and $\mathrm{C}_{0}$

\begin{tabular}{|c|c|c|c|c|c|c|}
\hline \multirow{2}{*}{ Parameter } & \multicolumn{3}{|c|}{ Wood ash } & \multicolumn{3}{|c|}{ Bone ash } \\
\hline & $q_{\mathrm{eq}}\left(\mathrm{mg} \mathrm{g}^{-1}\right)$ & $k_{2, \mathrm{ad}}\left(\mathrm{g} \mathrm{mg} \cdot \mathrm{min}^{-1}\right)$ & $R^{2}$ & $q_{\mathrm{eq}}\left(\mathrm{mg} \mathrm{g}^{-1}\right)$ & $k_{2, \text { ad }}\left(\mathrm{g} \mathrm{mg} \cdot \mathrm{min}^{-1}\right)$ & $R^{2}$ \\
\hline \multicolumn{7}{|l|}{$\mathrm{pH}$} \\
\hline 3 & 127 & 0.005 & 0.987 & 87.0 & 0.015 & 0.999 \\
\hline 4 & 152 & 0.04 & 0.998 & 123 & 0.009 & 0.997 \\
\hline 5 & 200 & 0.001 & 0.991 & 156 & 0.011 & 0.999 \\
\hline \multicolumn{7}{|l|}{$\mathrm{T}\left({ }^{\circ} \mathrm{C}\right)$} \\
\hline 20 & 200 & 0.001 & 0.991 & 40.7 & 0.012 & 0.999 \\
\hline 30 & 208 & 0.002 & 0.997 & 40.2 & 0.019 & 0.998 \\
\hline 40 & 227 & 0.002 & 0.999 & NA & NA & NA \\
\hline 50 & NA & NA & NA & 51.0 & 0.003 & 0.983 \\
\hline 60 & 200 & 0.002 & 0.989 & NA & NA & NA \\
\hline \multicolumn{7}{|l|}{$C_{S}\left(g^{-1}\right)$} \\
\hline 0.05 & 270 & 0.006 & 0.994 & NA & NA & NA \\
\hline 0.1 & 244 & 0.002 & 0.996 & 159 & 0.007 & 0.999 \\
\hline 0.2 & 263 & 0.002 & 0.998 & 75.2 & 0.161 & 0.998 \\
\hline 0.5 & 208 & 0.001 & 0.993 & 46.7 & 0.005 & 0.965 \\
\hline 0.75 & NA & NA & NA & 40.7 & 0.012 & 0.999 \\
\hline 1.0 & 103 & 0.009 & 0.982 & 36.0 & 0.004 & 0.979 \\
\hline \multicolumn{7}{|l|}{$C_{0}\left(\mathrm{mg} \mathrm{l}^{-1}\right)$} \\
\hline 100 & 103 & 0.009 & 0.982 & 40.7 & 0.012 & 0.999 \\
\hline 200 & 152 & 0.044 & 0.998 & 67.8 & 0.005 & 0.998 \\
\hline 300 & 238 & 0.001 & 0.994 & 85.5 & 0.004 & 0.995 \\
\hline
\end{tabular}

NA - not available 


\subsubsection{Equilibrium of sorption of $\mathrm{Cr}$ (III) ions}

Langmuir equation was used to model equilibrium between metal ions adsorbed to the biosorbent and metal ions in the solution at a given temperature. This model is simple and gives a good description of experimental behavior in a wide range of operating conditions (Yun et al., 2001). The main advantage of this model is the possibility of evaluation of $q_{\max }$ maximum possible quantity of metal ions adsorbed per gram of adsorbent $\left(\mathrm{mg} \mathrm{g}^{-1}\right)$ and $b$ constant related with the affinity of binding sites for the metal ions $\left(\mathrm{Img}^{-1}\right)$. In the literature it is reported, that Langmuir model was used to describe sorption of Direct blue 71 dye by palm ash (Ahmad et al., 2007) and cadmium and nickel onto bagasse fly ash (Srivastava et al., 2006).

The model parameters of Langmuir equation for sorption of $\mathrm{Cr}(\mathrm{III}), \mathrm{Cd}(\mathrm{II})$ and $\mathrm{Zn}(\mathrm{II})$ ions were determined by nonlinear regression (Mathematica v. 3.0). Table 5 presents the effect of temperature, $\mathrm{pH}$ and $C_{S}$ on model parameters.

Table 5. Model parameters of Langmuir isotherm for $\mathrm{Cr}(\mathrm{III})$ ions sorption by wood and bone ash

\begin{tabular}{|c|c|c|c|c|c|c|}
\hline \multirow{2}{*}{ Parameter } & \multicolumn{3}{|c|}{ Wood ash } & \multicolumn{3}{|c|}{ Bone ash } \\
\hline & $q_{\max }\left(\mathrm{mg} \mathrm{g}^{-1}\right)$ & $b\left(\mathrm{mg}^{-1}\right)$ & $R^{2}$ & $q_{\max }\left(\mathrm{mg} \mathrm{g}^{-1}\right)$ & $b\left(\mathrm{Img}^{-1}\right)$ & $R^{2}$ \\
\hline \multicolumn{7}{|l|}{$\mathrm{pH}$} \\
\hline 3 & 133 & 0.036 & 0.963 & 39.0 & 0.056 & 0.984 \\
\hline 4 & 196 & 0.786 & 0.971 & 63.5 & 0.025 & 0.951 \\
\hline $\begin{array}{l}5 \\
\mathrm{~T}\left({ }^{\circ} \mathrm{C}\right)\end{array}$ & 340 & 0.532 & 0.986 & 75.0 & 0.037 & 0.962 \\
\hline 20 & 315.7 & 1.03 & 0.973 & 75.0 & 0.037 & 0.962 \\
\hline 40 & 339.8 & 0.224 & 0.995 & 121 & 0.038 & 0.993 \\
\hline 60 & 325.1 & 0.653 & 0.991 & 140 & 0.160 & 0.996 \\
\hline \multicolumn{7}{|l|}{$C_{S}\left(g^{-1}\right)$} \\
\hline 0.1 & 498 & 0.106 & 0.978 & 277 & 0.090 & 0.973 \\
\hline 0.2 & 316 & 1.03 & 0.973 & 116 & 0.022 & 0.979 \\
\hline 0.5 & 252 & 0.963 & 0.957 & 56.9 & 0.069 & 0.989 \\
\hline 0.75 & NA & NA & NA & 75.0 & 0.037 & 0.962 \\
\hline 1.0 & NA & NA & NA & 55.0 & 0.014 & 0.991 \\
\hline 2.0 & NA & NA & NA & 42.0 & 0.030 & 0.994 \\
\hline
\end{tabular}

NA - not available

Results obtained in the equilibrium experiments confirmed the results from kinetic experiments. $\mathrm{pH}$ influenced the removal process in the highest extent. With increase of $\mathrm{pH}$, increase of $q_{\text {max }}$ for both bio-ashes was observed. From the Table 5 it can be seen that wood ash had much higher affinity towards $\mathrm{Cr}(\mathrm{III})$ ions, than bone ash (for example in $\mathrm{pH}$ 4: 0.786 I $\mathrm{mg}^{-1}$ and $0.025 \mathrm{I} \mathrm{mg}^{-1}$ for wood and bone ash, respectively). The influence of temperature on the model parameters of Langmuir isotherm was slight for wood ash similarly to its influence on pseudo-second order model parameters. This indicates that biosorption process is due to ion-exchange mechanism (Wang and Chen, 2006). For wood ash, $q_{\max }$ was $327 \mathrm{mg} \mathrm{g}^{-1}$ $( \pm 12.1)$. The highest affinity of wood ash towards $\operatorname{Cr}(\mathrm{III})$ ions was observed at $20^{\circ} \mathrm{C}(1.03 \mathrm{I}$ $\left.\mathrm{mg}^{-1}\right)$. In the case of bone ash, the highest $q_{\max }$ was obtained at $60^{\circ} \mathrm{C}$. With increase of temperature, the increase of affinity was observed. The effect of ash concentration on the equilibrium of sorption of $\mathrm{Cr}(\mathrm{III})$ ions by both ashes was investigated for $C_{\mathrm{S}} 0.1,0.2$ and $0.5 \mathrm{~g}$ $\mathrm{I}^{-1}$ and for bone ash also for three additional concentrations: $0.75,1.0$ and $2.0 \mathrm{~g} \mathrm{I}^{-1}$. The concentration of $\mathrm{Cr}$ (III) ions in the solutions after removal process was below detection limit $\left(\right.$ LD $\left.<0.0027 \mathrm{mg} \mathrm{l}^{-1}\right)$. This means, that the removal process for both ashes was very efficient. The highest amounts of removed $\mathrm{Cr}$ (III) ions were observed for the concentration of wood ash $-0.5 \mathrm{~g} \mathrm{l}^{-1}\left(126 \mathrm{mg} \mathrm{l}^{-1}\right)$. In the case of bone ash, the highest $q_{\max }$ and $b$, were obtained at $C_{\mathrm{s}} 0.1$ $\mathrm{g} \mathrm{I}^{-1}\left(277 \mathrm{mg} \mathrm{g}^{-1}\right.$ and $0.090 \mathrm{I} \mathrm{mg}^{-1}$, respectively). Preliminary experiments, which concerned the evaluation of the effect of temperature, $\mathrm{pH}$ and ash concentration on the equilibrium of $\mathrm{Cr}$ (III) ions sorption by wood and bone ash, were necessary to establish the best operation 
conditions, that would be used to remove toxic elements on larger scale. On the basis of the obtained results, the best process parameters for wastewater treatment with the utilization of

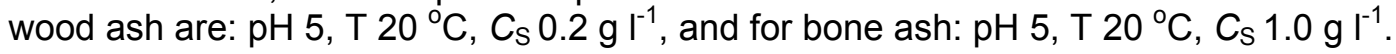

Additionally, equilibrium experiments were also conducted for $\mathrm{Zn}(\mathrm{II})$ and $\mathrm{Cd}(\mathrm{II})$ ions, which commonly pollute wastewaters. The experiments were performed at the following parameters: $1.0 \mathrm{~g} \mathrm{l}^{-1}, \mathrm{~T}^{\circ} 0^{\circ} \mathrm{C}, \mathrm{pH} 5, \mathrm{C}_{0} 25-300 \mathrm{mg} \mathrm{l}^{-1}$. The aim of these experiments was to determine Langmuir parameters: $q_{\max }$ and $b$. The obtained results are presented in Table 6 . The maximum sorption capacity of wood ash obtained for $\mathrm{Cd}(\mathrm{II})$ and $\mathrm{Zn}(\mathrm{II})$ ions was 4 and 12 times higher, than $q_{\max }$ obtained for bone ash, for these two metal ions, respectively. On the other hand, the affinity of the bone ash towards $\mathrm{Cd}(\mathrm{II})$ and $\mathrm{Zn}(\mathrm{II})$ ions was 9 and 6 times higher, than the affinity of wood ash towards these metal ions, respectively.

Table 6. Model parameters of Langmuir equation determined at $\mathrm{pH} 5,20^{\circ} \mathrm{C}$, bio-ash concentration $1.0 \mathrm{~g} \mathrm{I}^{-1}$

\begin{tabular}{ccccccc}
\hline Metal & \multicolumn{3}{c}{ Wood ash } & \multicolumn{3}{c}{ Bone ash } \\
\cline { 2 - 7 } ion & $q_{\max }\left(\mathrm{mg} \mathrm{g}^{-1}\right)$ & $b\left(\mathrm{I} \mathrm{mg}^{-1}\right)$ & $R^{2}$ & $q_{\max }\left(\mathrm{mg} \mathrm{g}^{-1}\right)$ & $b\left(\mathrm{I} \mathrm{mg}^{-1}\right)$ & $R^{2}$ \\
\hline $\mathrm{Cd}(\mathrm{II})$ & 210 & 0.278 & 0.984 & 57.1 & 2.61 & 0.982 \\
$\mathrm{Zn}(\mathrm{II})$ & 255 & 0.190 & 0.904 & 21.2 & 1.18 & 0.980 \\
\hline
\end{tabular}

\subsection{Batch sorption experiments in multi-metal system}

The efficiency of the sorption process in wastewater treatment depends not only on the ash properties but also on the sewage composition. The final aim of this paper was to determine the usefulness of wood and bone ash to remove toxic metals from effluents, which are generated by industry. In order to do that, two effluents were examined.

\subsubsection{Treatment of model wastewaters from metallurgical industry}

The treatment of the solution was performed at the best process parameters, which were established for equilibrium of sorption of $\mathrm{Cr}$ (III) ions. The concentrations of metal ions in the solution before and after treatment with bio-ashes are presented in Table 7.

Table 7. Treatment of wastewater from metallurgical with wood ash $\left(0.2 \mathrm{~g} \mathrm{I}^{-1}\right)$ and bone ash $\left(1.0 \mathrm{~g} \mathrm{l}^{-1}\right)$ at $\mathrm{pH} 5,20^{\circ} \mathrm{C}$

\begin{tabular}{|c|c|c|c|c|}
\hline \multirow{2}{*}{\multicolumn{2}{|c|}{ Element }} & \multicolumn{3}{|c|}{ Concentration $\left(\mathrm{mg} \mathrm{l}^{-1}\right)$} \\
\hline & & \multirow{2}{*}{ Before treatment } & \multicolumn{2}{|c|}{ After treatment with } \\
\hline & & & wood ash & bone ash \\
\hline \multirow{5}{*}{ 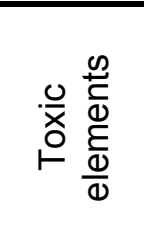 } & $\mathrm{Cd}$ & 15.5 & 4.59 & 9.24 \\
\hline & $\mathrm{Cu}$ & 7.22 & $0.52^{*}$ & $0.77^{*}$ \\
\hline & $\mathrm{Cr}$ & 19.6 & $0.18^{*}$ & 7.78 \\
\hline & $\mathrm{Ni}$ & 9.48 & 3.04 & 8.71 \\
\hline & $\mathrm{Zn}$ & 6.26 & LD $<0.0651^{*}$ & 3.21 \\
\hline \multirow{5}{*}{ 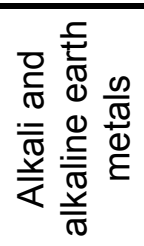 } & $\mathrm{K}$ & 6.48 & 21.5 & 15.2 \\
\hline & $\mathrm{Mg}$ & 0.08 & 1.82 & 3.67 \\
\hline & $\mathrm{Ca}$ & 2.63 & 32.7 & 23.1 \\
\hline & $\mathrm{Mn}$ & 0.002 & 0.06 & LD $<0.00091$ \\
\hline & $\mathrm{Ba}$ & 0.070 & 0.23 & $L D<0.0003^{*}$ \\
\hline
\end{tabular}

LD - below detection limit

*fulfil the Directive of Polish Minister of Agriculture and Rural Development - the acceptable concentrations of metal ions in discarded to soil and water solutions (2006)

The analysis of the Table 7 showed, that wood ash turned out to be very efficient material for toxic metal ions: $\mathrm{Cr}(\mathrm{III}), \mathrm{Cu}(\mathrm{II}), \mathrm{Cd}(\mathrm{II}), \mathrm{Ni}(\mathrm{II})$ and $\mathrm{Zn}(\mathrm{II})$. The percentage of the metal ions removed from the model solution was as follows: $99.1 \%, 92.8 \%, 70.4 \%, 67.9 \%$ and $>99.0 \%$, respectively. The efficiency of bone ash to remove metal ions was lower and the 
percentage of the removal of metal ions ranged from $8.2 \%$ for $\mathrm{Ni}(\mathrm{II})$ ions to $89.3 \%$ for $\mathrm{Cu}$ (II) ions. In spite of the relatively high efficiency of both ashes, obtained solutions can not be discarded into water or soil, because they do not fulfil Polish law - the concentration of metal ions was too high. According to the Directive of Polish Minister of Agriculture and Rural Development (2006), the concentration of metal ions in the discarded solutions should be as follows: Cd 0.05-0.4 $\mathrm{mg} \mathrm{l}^{-1}$, Zn $2.0 \mathrm{mg} \mathrm{l}^{-1}$, Cr total 0.5-1.0 $\mathrm{mg} \mathrm{l}^{-1}$, Cu, Ni 0.1-0.5 mg I-1, Ba 2.0$3.0 \mathrm{mg} \mathrm{l}^{-1}$. Generally, wood ash was found to be an efficient material for removal of $\mathrm{Cu}$ (II), $\mathrm{Cr}(\mathrm{III}), \mathrm{Zn}(\mathrm{II})$ and $\mathrm{Ba}(\mathrm{II})$, but not for $\mathrm{Cd}(\mathrm{II})$ and $\mathrm{Ni}(\mathrm{II})$. In the case of bone ash, removal of $\mathrm{Cu}(\mathrm{II})$ and $\mathrm{Ba}(\mathrm{II})$ ions fulfilled Polish norms. In order to decrease the concentration of metal ions in the treated effluent, higher concentrations of ash should be applied. It is also important to emphasize, that the concentration of all toxic elements in the solution after treatment with bioashes was smaller than before removal process. This means that bio-ashes did not cause secondary pollution of the effluent.

The multielemental analysis of the model solutions after removal process revealed the presence of higher concentrations of alkali $(\mathrm{K}(\mathrm{I}))$ and alkaline earth metals $(\mathrm{Mg}(\mathrm{II}), \mathrm{Ca}(\mathrm{II})$, $\mathrm{Ba}(\mathrm{II}))$ than in the initial solution. These ions, which originate from natural ashes, were released during treatment, which caused precipitation of toxic metals hydroxides. In the case of wood ash, $10.2 \mathrm{meq} \mathrm{g}^{-1}$ of light metals ( $\mathrm{Mg}(\mathrm{II}), \mathrm{Ca}(\mathrm{II}), \mathrm{Ba}(\mathrm{II}), \mathrm{K}(\mathrm{I}), \mathrm{Mn}(\mathrm{II})$ ) were released from the ash to the solution during removal process, and $8.72 \mathrm{meq} \mathrm{g}^{-1}$ of toxic metals (Cd(II), $\mathrm{Cr}(\mathrm{III}), \mathrm{Cu}(\mathrm{II}), \mathrm{Ni}(\mathrm{II}))$ were removed from the effluent by the wood ash. For bone ash, the sum of light metals ( $\mathrm{Mg}(\mathrm{II}), \mathrm{Ca}(\mathrm{II}), \mathrm{K}(\mathrm{I})$ ), released was equal $1.54 \mathrm{meq}^{-1}$, and the sum of toxic metals (Cd(II), $\mathrm{Cr}(\mathrm{III}), \mathrm{Cu}(\mathrm{II}), \mathrm{Zn}(\mathrm{II})$ and $\mathrm{Ni}(\mathrm{II}))$ bound by the ash was $1.12 \mathrm{meq}^{-1}$.

\subsubsection{Treatment of effluent from the production process of biological feed additives with microelements from microalgae using a biosorption process}

The second solution for the removal of toxic elements was acquired from the production process of biological feed additives. This process relies on the enrichment of the biomass of alga with microelements (e.g. $\mathrm{Cr}$ (III) ions) via biosorption process. As a result, after the process, the solutions with high concentration of $\mathrm{Cr}(\mathrm{III})$ ions were obtained.

Multielemental analysis of the solution before and after treatment with bio-ashes revealed that mainly alkali and alkaline earth metal ions were released to the solution: $\mathrm{Ca}(\mathrm{II}), \mathrm{K}(\mathrm{I}), \mathrm{Mg}(\mathrm{II})$, $\mathrm{Na}$ (I) (Table 8). For wood ash $31.4 \mathrm{meq} \mathrm{g}^{-1}$ of light metals were released and for bone ash $5.15 \mathrm{meq} \mathrm{g}^{-1}$. The concentration of $\mathrm{Cr}$ (III) ions was reduced from $190 \mathrm{mg} \mathrm{l}^{-1}$ to $29.4 \mathrm{mg} \mathrm{I}^{-1}$ by wood ash $\left(0.2 \mathrm{~g} \mathrm{I}^{-1}\right)$ and to $114 \mathrm{mg} \mathrm{l}^{-1}$ by bone ash $\left(1.0 \mathrm{~g} \mathrm{I}^{-1}\right)$ and the concentration of $\mathrm{Cd}$ (II) was reduced by $45.1 \%$ by wood ash and by $84.5 \%$ by bone ash. Nevertheless, the concentration of $\mathrm{Cr}(\mathrm{III})$ ions in the solution after treatment with wood and bone ash did not fulfil Polish norms (Directive of Polish Minister of Agriculture and Rural Development, 2006). The concentration of other elements in the solution after removal is in an acceptable by Polish law range (with exception of $\mathrm{Sb}$ for bone ash - $0.3 \mathrm{mg} \mathrm{l}^{-1}$ ). Higher removal efficiencies are possible after treatment with higher concentrations of bio-ashes.

\section{CONCLUSIONS}

In the present paper, sorption process was used to remove toxic elements from aqueous solution using two natural materials - wood and bone ash. The preliminary studies showed, that the removal process depended on $\mathrm{pH}$, ash concentration, initial metal ions concentration and in slight extent on temperature. These studies enabled to characterize sorption properties of bio-ashes and to establish the experimental conditions, in which the highest efficiency of metal ions removal was observed. The best experimental conditions for removal of metal ions from wastewaters were established as: $\mathrm{pH} 5, \mathrm{~T}^{\circ} 0^{\circ} \mathrm{C}$ and $C_{S} 0.2 \mathrm{~g} \mathrm{l}^{-1}$ for wood ash and $\mathrm{pH}$, $\mathrm{T} 20{ }^{\circ} \mathrm{C}, \mathrm{C}_{\mathrm{S}} 1.0 \mathrm{~g} \mathrm{l}^{-1}$ for bone ash. Wood ash was found to be a better sorbent for toxic cations than bone ash. At the same experimental conditions $\left(C_{S} 0.1 \mathrm{~g} \mathrm{l}^{-1}, C_{0} 100 \mathrm{mg} \mathrm{l}^{-1}, \mathrm{pH} 4, \mathrm{~T} 20\right.$ $\left.{ }^{\circ} \mathrm{C}\right), q_{\text {eq }}$ for the removal of $\mathrm{Cr}$ (III) ions by wood ash was 2 times higher $\left(244 \mathrm{mg} \mathrm{g}^{-1}\right)$ than for bone ash $\left(123 \mathrm{mg} \mathrm{g}^{-1}\right)$. The same effect was observed for other toxic elements. The maximum sorption capacity of wood ash obtained for $\mathrm{Cd}(\mathrm{II})$ and $\mathrm{Zn}$ (II) ions was 4 and 12 times higher, than $q_{\max }$ obtained for bone ash, for these two metal ions, respectively. 
Table 8. Treatment of wastewater from biosorption process containing high concentrations of $\mathrm{Cr}(\mathrm{III})$ ions with wood ash $\left(0.2 \mathrm{~g} \mathrm{l}^{-1}\right)$ and bone ash $\left(1.0 \mathrm{~g} \mathrm{l}^{-1}\right)$ at $\mathrm{pH} 5,20^{\circ} \mathrm{C}$

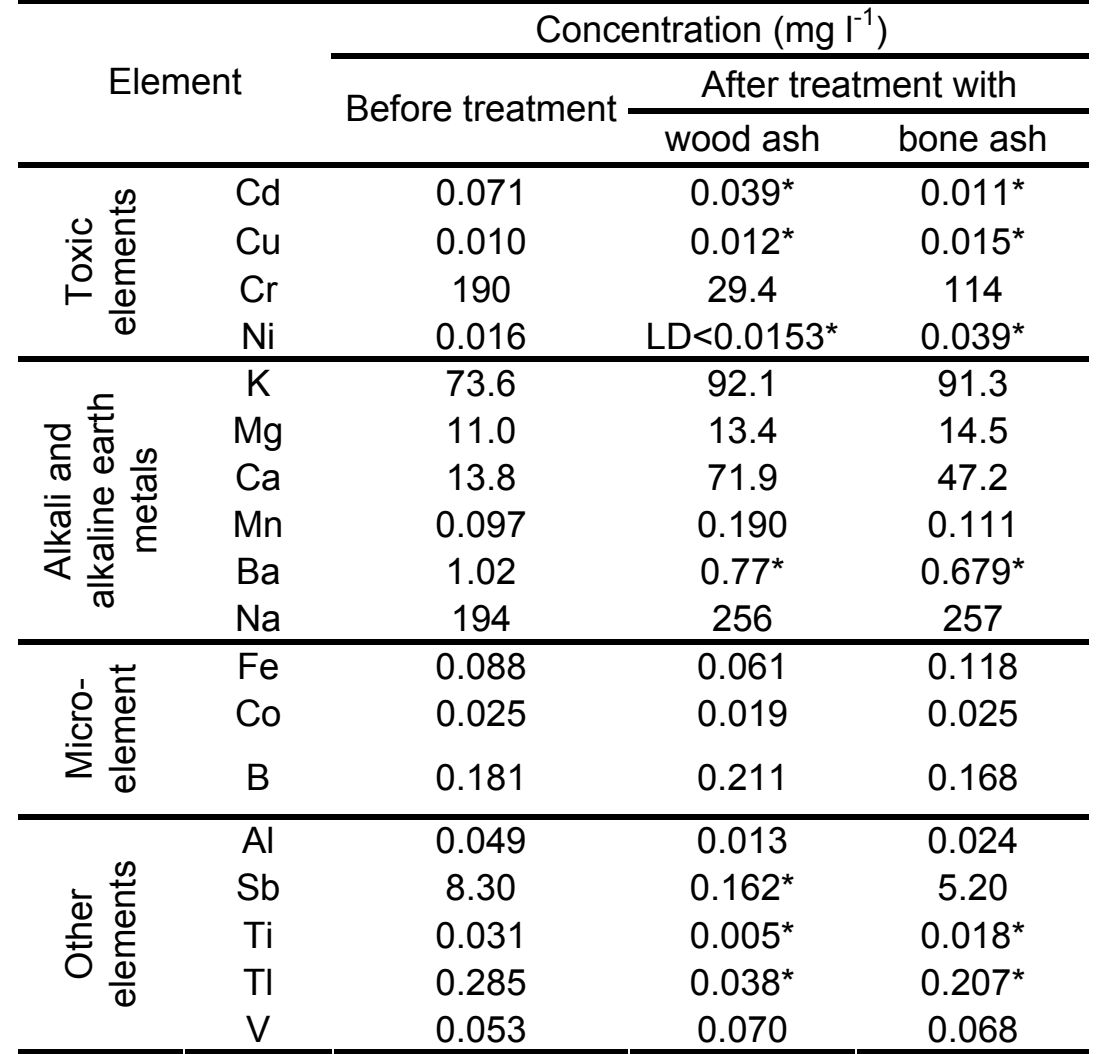

LD - below detection limit

* fulfil the Directive of Polish Minister of Agriculture and Rural Development

- the acceptable concentrations of metal ions in discarded to soil and water solutions (2006)

The key issue of this paper was to determine the usefulness of wood and bone ash in the removal of toxic metal ions from effluents, which are generated by industry. The promising results were obtained for wood ash. The percentage of the metal ions removed from the model solution from metallurgical industry by wood ash ranged from $67.9 \%$ for $\mathrm{Ni}(\mathrm{II})$ ions to $99.1 \%$ for $\mathrm{Cr}$ (III) ions at only $0.2 \mathrm{~g} \mathrm{I}^{-1}$ of the ash, whereas for bone ash from $8.2 \%$ for $\mathrm{Ni}(\mathrm{II})$ ions to $89.3 \%$ for $\mathrm{Cu}(\mathrm{II})$ ions, even if 5 times higher concentration of the ash was applied. After the treatment of the effluent from the production process of biological feed additives from microalgae, which was rich in $\mathrm{Cr}(\mathrm{III})$ ions, wood ash was capable of reducing $\mathrm{Cr}$ (III) ions concentration $84.5 \%$ and bone ash only $40 \%$.

It is also important to emphasize, that removal of metal ions from aqueous solutions is a complex process. It can be expected that metal ions can be removed from aqueous solutions by precipitation, electrostatic adsorption and ion exchange. The presence of light metals in the solution after removal process indicated, that one of the possible mechanisms was ionexchange or dissolution of light metals and precipitation of toxic hydroxides. The potentiometric titration of ashes confirmed, that on the sorbent surface were present three functional groups, which were responsible for cation removal. The total cation removal capacity of wood ash was 37.3 meq g$~^{-1}$ and of bone ash $15.2 \mathrm{meq} \mathrm{g}^{-1}$. This means, that theoretical $q_{\max }$ of wood ash towards toxic elements was evaluated as: $q_{\max } \operatorname{Cr}(\mathrm{III}) 647 \mathrm{mg} \mathrm{g}^{-1}$, $q_{\max } \mathrm{Cu}(\mathrm{II}) 1185 \mathrm{mg} \mathrm{g}^{-1}$ and $q_{\max } \mathrm{Cd}$ (II) $2096 \mathrm{mg} \mathrm{g}^{-1}$, and for bone ash as: $q_{\max } \mathrm{Cr}$ (III) $264 \mathrm{mg} \mathrm{g}^{-1}$, $q_{\max } \mathrm{Cu}(\mathrm{II}) 483 \mathrm{mg} \mathrm{g}^{-1}$ and $q_{\max } \mathrm{Cd}(\mathrm{II}) 854 \mathrm{mg} \mathrm{g}^{-1}$. These results showed, that wood ash has higher potential to remove toxic elements from wastewaters. Theoretically, wood ash is able to bind 2.5 times more of toxic metals than bone ash.

Removal process described in this paper incorporating the utilization of bio-ashes as sorbents can be used in the future as an alternative method of wastewater treatment. These biosorbents could be therefore substituted in place of activated carbon or ion-exchange resins 
as metal ions removal agents due to their availability, high adsorption capacity and low cost. Nevertheless, there is a necessity to perform further experiments, especially on real industrial effluents.

\section{ACKNOWLEDGEMENT}

This research was financially supported by Ministry of Science and Higher Education (3 T09B 148 29 and R05 01401 ).

\section{REFERENCES}

Ahmad, A.A., B.H. Hameed and Aziz, N. (2007), Adsorption of direct dye on palm ash: Kinetic and equilibrium modeling, Journal of Hazardous Materials, 141, 70-76.

Alinnor, I.J. (2007), Adsorption of heavy metal ions from aqueous solution by fly ash, Fuel, 86, 853-857.

Al-Asheh, S., Banat, F. and Mohai, F. (1999), Sorption of copper and nickel by spent animal bones, Chemosphere, 39, 2087-2096.

Al-Asheh, S., Abdel-Jabar, N. and Banat, F. (2002), Packed-bed sorption of copper using spent animal bones: factorial experimental design, desorption and column regeneration, Advances in Environmental Research, 6, 221-227.

Banat, F., Al-Asheh, S. and Mohai, F. (2000), Batch zinc removal from aqueous solution using dried animal bones, Separation and Purification Technology, 21, 155-164.

Chaala, A. and Roy, C. (2003), Recycling of Meat and Bone Meal Animal Feed by Vacuum Pyrolysis, Environmental Science and Technology, 37, 4517-4522.

Charerntanyarak L. (1999), Heavy metals removal by chemical coagulation and precipitation, Water Science and Technology, 39, 135-138.

Cho, H., Oh, D. and Kim, K. (2005), A study on removal characteristics of heavy metals from aqueous solution by fly ash, Journal of Hazardous Materials, B127, 187-195.

Chojnacka, K. (2005), Equilibrium and kinetic modeling of chromium(III) sorption by animal bones, Chemosphere, 59, 315-320.

Chojnacka, K., Chojnacki, A. and Górecka, H. (2005), Biosorption of $\mathrm{Cr}^{3+}, \mathrm{Cd}^{2+}$ and $\mathrm{Cu}^{2+}$ ions by blue-green algae Spirulina sp.: kinetics, equilibrium and the mechanism of the process, Chemosphere, 59, 75-84.

Chojnacka, K. (2006), The application of multielemental analysis in the elaboration of technology of mineral feed additives based on Lemna minor biomass, Talanta, 70, 966-972.

Chojnacka, K. (2007), Using biosorption to enrich the biomass of Chlorella vulgaris with microelements to be used as mineral feed supplement, World Journal of Microbiology and Biotechnology, 23, 1139-1147.

Conesa, J.A., Fullana, A. and Font, R. (2005), Dioxin production during the thermal treatment of meat and bone meal residues, Chemosphere, 59, 85-90.

Das, B., Hazarika, P., Saikia, G., Kalita H., Goswami, D.C., Das, H.B., Dube, S.N. and Dutta, R.K. (2007), Removal of iron from groundwater by ash: A systematic study of a traditional method, Journal of Hazardous Materials, 141, 834-841.

Demeyer, A., Voundi Nkana, J.C. and Verloo, M.G. (2001), Characteristics of wood ash and influence on soil properties and nutrient uptake: an overview, Bioresource Technology, 77, 287295.

Deydier, E., Guilet, R. and Sharrock, P. (2003), Beneficial use of meat and bone meal combustion residue: "an efficient low cost material to remove lead from aqueous effluent", Journal of Hazardous Materials, B101, 55-64.

Directive of Polish Minister of Agriculture and Rural Development, (2006) The acceptable concentrations of metal ions in discarded to soil and water solutions, Journal of Laws, No. 137, Item 984 (in Polish).

Erol, M., Küçükbayrak, S., Ersoy-Meriçboyu, A. and Ulubaş, T. (2005), Removal of Cu2+ and $\mathrm{Pb} 2+$ in aqueous solutions by fly ash, Energy Conversion and Management, 46, 1319-1331.

Górecka, H., Chojnacka, K. and Górecki, H. (2006), The application of ICP-MS and ICP-OES in determination of micronutrients in wood ashes used as soil conditioners, Talanta, 70, 950-956.

Łebkowska, M. and Karwowska, E. (2003), The removal of toxic metals from sewage and sludge, Warszawa PzliTS (in Polish).

Reijnders, L. (2005), Disposal, uses and treatments of combustion ashes: a review, Resources, Conservation and Recycling, 43, 313-336.

Ribbing, C. (2007), Environmentally friendly use of non-coal ashes in Sweden, Waste Management, 27, 1428-1435. 
Srivastava, V.C., Deo Mall, I. and Mishra, I.M. (2006), Equilibrium modelling of single and binary adsorption of cadmium and nickel onto bagasse fly ash, Chemical Engineering Journal, 117, 79-91.

Yongnian, N., Shouhui, C. and Serge, K. (2002), Spectrophotometric determination of metal ions in electroplating solutions in the presence of EDTA with the aid of multivariate calibration and artificial neural networks, Analytica Chimica Acta, 463, 305-316.

Yun, Y.S., Park, D., Park, J.M. and Volesky, B. (2001), Biosorption of Trivalent Chromium on the Brown Seaweed Biomass, Environmental Science and Technology, 35, 4353-4358.

Veglio, F. and Beolchini, F. (1997), Removal of metals by biosorption: a review, Hydrometallurgy, 44, 301-316.

Volesky, B. (1990), Biosorption and biosorbents In: Biosorption of Heavy Meatals, Volesky B. (ed.), CRC press, Boca Raton.

Wang, J. and Chen, C. (2006), Biosorption of heavy metals by Saccharomyces cerevisiae: A review, Biotechnology Advances, 24, 427-451.

Wang, J., Teng, X., Wang, H. and Ban, H. (2004), Characterizing the Metal Adsorption Capability of a Class F Coal Fly Ash, Environmental Science and Technology, 38, 6710-6715. 